Portland State University

PDXScholar

\title{
Multiple Methods of Public Engagement: \\ Disaggregating Socio-spatial Data for Environmental Planning in Western Washington, USA
}

Rebecca J. McLain

Portland State University, mclainrj@pdx.edu

David Banis

Portland State University, dbanis@pdx.edu

Alexa Todd

Portland State University

Lee Cerveny

US Forest Service Pacific Northwest Research Station

Follow this and additional works at: https://pdxscholar.library.pdx.edu/geog_fac

Part of the Physical and Environmental Geography Commons, and the Sustainability Commons Let us know how access to this document benefits you.

\section{Citation Details}

McLain, R. J., Banis, D., Todd, A., \& Cerveny, L. K. (2017). Multiple methods of public engagement: Disaggregating socio-spatial data for environmental planning in western Washington, USA. Journal of Environmental Management. 204: 61-74., 204, 61-74.

This Article is brought to you for free and open access. It has been accepted for inclusion in Geography Faculty Publications and Presentations by an authorized administrator of PDXScholar. Please contact us if we can make this document more accessible: pdxscholar@pdx.edu. 
Research article

\title{
Multiple methods of public engagement: Disaggregating socio-spatial data for environmental planning in western Washington, USA
}

\author{
Rebecca J. McLain ${ }^{\text {a, }}{ }^{,}$, David Banis ${ }^{\mathrm{b}}$, Alexa Todd ${ }^{\mathrm{b}}$, Lee K. Cerveny ${ }^{\mathrm{c}}$ \\ a Institute for Sustainable Solutions, Portland State University, 1600 SW 4th Avenue, Suite 110, Portland, OR, 97201, USA \\ b Department of Geography, Portland State University, 1721 SW Broadway, Cramer Hall, Rm 424, Portland, OR, 97201, USA \\ ${ }^{c}$ US Department of Agriculture, Forest Service, Pacific Northwest Research Station, 400 N 34th St. Suite 201, Seattle, WA, 98103, USA
}

\section{A R T I C L E I N F O}

\section{Article history:}

Received 5 October 2016

Received in revised form

10 July 2017

Accepted 22 August 2017

\section{Keywords:}

Public participation GIS

Social values

Environmental planning

Forest transportation planning

Stakeholder participation

Public involvement

\section{Introduction}

Environmental planners and conservation scientists emphasize the importance of taking into account the cultural services provided by ecosystems when making environmental management decisions (Daniel et al., 2012). The Millennium Ecosystem Services Assessment (MEA) (2005: 8) defines cultural services as the "nonmaterial benefits people obtain from ecosystems through spiritual enrichment, cognitive development, reflection, recreation, and aesthetic experiences." Included among these benefits are "cultural diversity, spiritual and religious values, knowledge systems, educational values, inspiration, aesthetic values, social relations, sense of place, cultural heritage values, recreation and ecotourism" (Daniel et al., 2012). Rawluk et al. (2017: 13) argue that knowing which attributes the public values in a given landscape is important because such knowledge "can support the alignment of policy and planning to social priorities and expectations." Environmental planning processes that engage multiple publics are an important means by which environmental managers can identify a

\footnotetext{
* Corresponding author.

E-mail address: mclainrj@pdx.edu (R.J. McLain).
}

broad range of uses and values assigned to areas that are targeted for management actions (Ellis et al., 2010; Luyet et al., 2012; Reed, 2008).

Recent studies indicate that public participation GIS (PPGIS) has the potential to expand the ability of managers to reach a broad spectrum of the public during environmental planning processes (Brown and Kyttä, 2014). Tulloch (2008: 353) define PPGIS as a "field within geographic information science that focuses on ways the public uses various forms of geospatial technologies to participate in public processes, such as mapping and decision making." By linking uses and values to locations in the form of GIS data layers, PPGIS facilitates environmental planning analyses that account for social values (Sherrouse et al., 2011). The social data layers created through PPGIS can be structured for use with analytical techniques such as an analytical hierarchical process (AHP), which combines qualitative and quantitative factors for ranking and evaluating alternative scenarios (Bathrellos et al., 2012). Bathrellos et al. (2013) combined socioeconomic data along with geological and natural hazard data to develop rural development and urban suitability maps (Bathrellos et al., 2013, 2017). Brown and Reed (2012) used a variant of the AHP approach, known as values compatibility analysis, to develop an all-terrain vehicle use suitability map for a national forest in Oregon, USA that incorporated social values data collected through a PPGIS process.

PPGIS projects engage the public in a variety of ways, ranging from mail, Internet, or in-person surveys to community workshops and focus groups (Brown and Kyttä, 2014; McLain et al., 2013b). They also employ diverse technologies, including paper maps, interactive online maps, and offline computerized mapping applications. As PPGIS becomes more widely used, the question of which publics PPGIS engages assumes greater importance (Brown, 2012). Decisions based on input from one public may have unanticipated or disproportionately negative impacts on unrepresented publics. And decisions made without input from key segments of the public may prove difficult to implement. However, determining who constitutes the relevant public is challenging (Predmore et al., 2011). Factors such as geographic scope, the issues involved, and who has relevant knowledge all affect which publics are relevant for a particular planning process (Schlossberg and Shuford, 2005). 
Most planning situations involve multiple relevant publics, each with its own set of interests and differing levels of comfort with various forms of public engagement (Glucker et al., 2013; Haddock and Quinn, 2016). Gaining a better understanding of which publics are likely to be reached with which PPGIS approaches is of critical importance if such projects are to expand public input into environmental decision-making.

In a review of PPGIS studies conducted primarily in the global North, Brown (2012) found that participants tended to be disproportionately older, white men with relatively high levels of income and formal education. There are exceptions to this tendency, however. Pert et al.'s (2015) indigenous cultural ecosystem services mapping project in Australia and Carver et al.'s (2009) use of PPGIS for fire management planning in Montana both involved only members of indigenous groups. Only a few studies (Brown et al., 2014; Pocewicz et al., 2012) compare how the type of PPGIS approach or technology used affects who participates. These studies are ambiguous as to whether different types of participants differ in the values they assign to the landscape or in their environmental management preferences. Pocewicz et al. (2012) found that PPGIS participants in Wyoming who used paper maps tended to be older, had lived in the area longer, and had less formal education than respondents who completed the same survey online. Yet, both groups mapped similar places and gave similar reasons for why those places were important. In contrast, Brown et al. (2014) found that participants in a landscape values mapping workshop were more likely to be men and somewhat older than those who did the values mapping online. Additionally, rural residents were less likely than urban residents to participate in the online survey (Brown et al., 2014). They found relatively little overlap in the spatial location of sites marked by the two sets of participants. Sites considered important for recreation, however, overlapped 67 percent of the time. As PPGIS becomes more widely used, additional studies regarding differences in who participates in workshop and online processes are needed so that managers can develop outreach strategies that are more effective at reaching a greater diversity of population subgroups.

Factors that have been found to affect the types and locations of mapped activities, values, or management preferences include livelihood occupation (Brown et al., 2015a), community of residence (Alessa et al., 2008; Beverly et al., 2008), stakeholder group (Brown et al., 2015b), self-reported familiarity with the area (Brown and Weber, 2011), income (Brown and Weber, 2011), and proximity of domicile to study or project site (Brown, 2016). Of these factors, residence location has emerged as particularly important in shaping what values people map and where they map them (Brown, 2016). PPGIS participants have a tendency to map values or activity sites that are close to home (Beverly et al., 2008; McLain et al., 2013a) and assign high values to places near their homes (Alessa et al., 2008). Pocewicz and Nielsen-Pincus (2013) documented a phenomenon known as geographic discounting, in which individuals mapped positive biological conditions and land use preferences closer to their homes and negative conditions and land use preferences further from their homes. Sociological studies show that significant differences exist between urban and rural residents' outdoor recreation activities (Cordell, 2012; Dwyer, 1994). However, only one PPGIS study (Brown et al., 2015a) has looked explicitly at how values mapping patterns differ along an urban-rural continuum. That study showed that rural landholders' values were concentrated in smaller areas and located closer to their homes than those of urban or semi-urban landholders. Brown (2016) reported that differences in place of residence was one of two conditions associated with higher potential for mapping bias and calls for research that pays attention to geographical representativeness in PPGIS projects.
The need for public engagement strategies to consider the role of place and community type has become apparent (Pert et al., 2015). Measham et al. (2011) found that residents of isolated dryland communities in Australia faced significant barriers to participating in government-run community engagement processes owing to the long distances and pressing seasonal work demands that residents in urban areas did not face. Efforts to implement interactive web-based public engagement forums in England for flood risk management (White et al., 2010) and urban development in Toronto (Rinner and Bird, 2009) indicated that online applications can improve the reach of engagement processes, however, they may not be effective at reaching population segments that are less technologically inclined. Differential participation in the face-to-face dialogue and interactive web engagement processes described above suggest that what works in one context may not work in another, and that there is therefore a need for multiple engagement strategies when engaging with different communities.

The primary aim of this article is to enhance understanding about how two commonly used PPGIS approaches-community workshops and internet surveys-differ in who they bring to the environmental planning table. A secondary aim is to expand knowledge about favored destinations and activities associated with public forest road networks, with a focus on exploring how favored destinations and activities differ for urban and rural residents. Our study contributes to the field of environmental planning and management in several ways. First, it helps fill the gap in knowledge about whether and how different types of PPGIS approaches differ in terms of the publics that they are able to engage in environmental deliberation processes. Second, very little research has been published regarding the uses and values different segments of the public associate with forest road networks on public lands. Given that many countries have extensive forest road networks on public lands, this is an important knowledge gap that our study addresses. From a practical standpoint, the lessons learned from this PPGIS project can inform the development of more effective and broader reaching PPGIS strategies and data analysis procedures for a variety of environmental planning situations.

\section{Study area}

This study took place in the Mt. Baker-Snoqualmie National Forest (MBSNF) located in Washington (USA) on the western slope of the Cascade Mountain Range. The $6870 \mathrm{sq} \mathrm{km}$ forest borders Canada on the north and extends south 370 miles to Mt. Rainier National Park (United States Department of Agriculture, Forest Service (USDA-FS), 1990). The national forest includes nine wilderness areas (covering $3340 \mathrm{sq} \mathrm{km}$ ) and provides access to two heavily visited national parks, North Cascades and Mt. Rainier. Steep topography and dense vegetation make travel through and across the MBSNF and surrounding areas difficult and most major transportation routes closely follow rivers. The MBSNF is categorized as an urban national forest because of its proximity to several large urban areas. Parts of the forest are located $70 \mathrm{~km}$ east of the Seattle metropolitan area (pop 3.7 million) (US Census Bureau, 2015). The northern part of the forest is located within $70 \mathrm{~km}$ of the Vancouver, BC metropolitan area (pop 2.5 million) (British Columbia, 2016). Dozens of rural communities with a long history of reliance on timber and other natural resources derived from the national forest also are an important part of the MBSNF's socioeconomic fabric. With 2.0 million annual visitors, the MBSNF is one of the most heavily visited national forest in the United States (USDA-FS, 2010). The most popular activities for visitors are hiking, downhill skiing, and scenic viewing (USDA-FS, 2010). Four major 
highways cross the Cascades within the forest's boundaries, providing ready access to some areas of the forest. Much public use of the MBSNF occurs along or near these roads.

The MBSNF has a dense forest road network that was constructed to move logs out of the woods. However, a steady decline in timber sales and associated road maintenance funds since the 1990s has left the MBSNF struggling to maintain its road system (USDA-FS, 2015a). In 2005, the US Forest Service adopted a Travel Management Rule aimed at decreasing the gap between current forest revenues and road maintenance costs. The travel management regulations required each national forest to conduct a science-based travel analysis to identify roads likely be needed in the future and roads likely not needed (USDA-FS, 2012). The travel analyses provide the foundation for the eventual development of travel management plans in which the national forests will designate which roads to maintain and which to close temporarily or permanently. Public lands access in the western United States is highly controversial, with longstanding tensions between advocates for eliminating or restricting human uses of public lands and those seeking to maintain or expand human uses of such lands (Havlick, 2002). Although not required to involve the public in travel analyses, many national forests opted to do so in order, to reduce the likelihood of political resistance to the eventual travel management plans.

When the PPGIS processes described in our case study began, the MBSNF was one of many national forests that had yet to begin its travel analysis. In response to concerns by local grassroots organizations about the prospect of losing access to forest roads, MBSNF officials implemented a public engagement process aimed at eliciting data about which roads the public used and the reasons they used them. The intent was to produce socio-spatial data that the MBSNF Interdisciplinary Team could incorporate into its Sustainable Roads Strategy and integrate with data from hydrologists, engineers, wildlife and aquatic biologists, recreation planners, and other technical specialists. The public road use data gathered using PPGIS methods would be analyzed along with these other data to prioritize which roads to maintain in the future as well as their levels of maintenance.

\section{Methods}

Public engagement in the MBSNF was conducted in partnership with a loosely organized group of local stakeholders and community organizations known as the Sustainable Roads Cadre (SRC). Led by the Wilderness Society and the Washington Trails Association, the SRC included 45 organizations representing a wide variety of interests, including off-road vehicle users, timber companies, tourism providers, and pro-forest access voices. Two public engagement methods were used to promote dialogue and gather public input. The first approach was a series of community workshops held from June to November 2013 (Fig. 1). The intent of the workshops was to engage local stakeholders in constructive dialogue and to build trust while gathering information about forest road use. The second approach was an online survey hosted by the SRC that mirrored the questions asked during the workshops. The survey allowed participation from non-local stakeholders as well as local residents who could not attend workshops. The online survey was active from June to November 2013. The MBSNF made preliminary results of the public engagement processes available to the public in fall 2015 (USDA-FS, 2015b).

\subsection{Community workshops}

Participants for the workshops were recruited by the SRC and MBSNF with help from the media. Eight workshops were held in both urban and rural communities $(\mathrm{n}=262$ ). The number of participants ranged from 22 to 52 per workshop, with an average of 31 . The workshops featured two activities. The first was a mapping exercise where participants marked priority forest destinations on maps and identified the roads they used to access those destinations. Participants also completed a short demographic questionnaire, which included questions about the frequency of forest visits, use of forest roads, and forest management values. Participants gathered around tables with two facilitators. Two large maps (48 $\times 24$ inches) on each table featured the northern and southern segments of the MBSNF. Each person received a worksheet that posed the question 'What are the eight destinations on the MBS that are important to you?' For each place indicated, participants were asked why that destination was important, what activities they did there, how often they visited it, and what kind of vehicle they used to travel there. Participants placed a dot sticker on the MBSNF map for each destination noted, and then they used a highlighter pen to trace the route they travel to reach that destination. The average number of destinations and routes identified per participant was just over seven. After the mapping session, table groups gathered for facilitated discussions around the challenges and opportunities related to changes in the size of the road system.

\subsection{Online questionnaire}

The online survey allowed the SRC to engage local residents who could not attend a workshop as well as non-local stakeholders. However, insufficient resources were $t$ available to develop an interactive online mapping application. The Washington Trails Association, a member of the SRC, designed and hosted the survey on its website; links to the survey were provided on both the SRC and MBSNF websites. In all, 1548 individuals responded to the survey. The questionnaire could be accessed from an IP address multiple times; roughly 50 instances of this occurred. Since the participants may have been different individuals using the same computer they were treated as distinct cases. Thirty-seven of the online survey participants also attended a workshop. Their responses were included in both the online survey and the workshop analyses since the intent was to compare differences between online and workshop participants. Participants had access to a pdf version of a map of the MBSNF road system for reference on the SRC website, but could not mark directly on the map. Instead they provided place names and used road names or road numbers to show how they the accessed their important places. About half of the people who logged into the survey provided no spatial data. Of participants who provided spatial data, 727 noted at least one destination that could be mapped. There was a consistent drop-off in the number of participants who identified multiple destinations, with 290 providing four destinations and only 10 noting eight destinations; the average number of destinations noted per participant was just over three.

\subsection{Developing maps from the workshop and online survey data}

GIS data were created in ArcGIS 10.2.2 from the workshop map markings using a comprehensive dataset of roads obtained from the MBSNF. Destination points were digitized as placed on the map, with a few exceptions. It is helpful to think about the destinations as places at or near where people parked their cars, and to recognize that in many cases the participants would then go by foot, horseback, bicycle, skis, snowmobile, or all-terrain vehicle to some place further from the road. Mapped destinations varied in precision as a result of the shared use of each map by multiple participants, some of whom marked destinations with the same spatial 


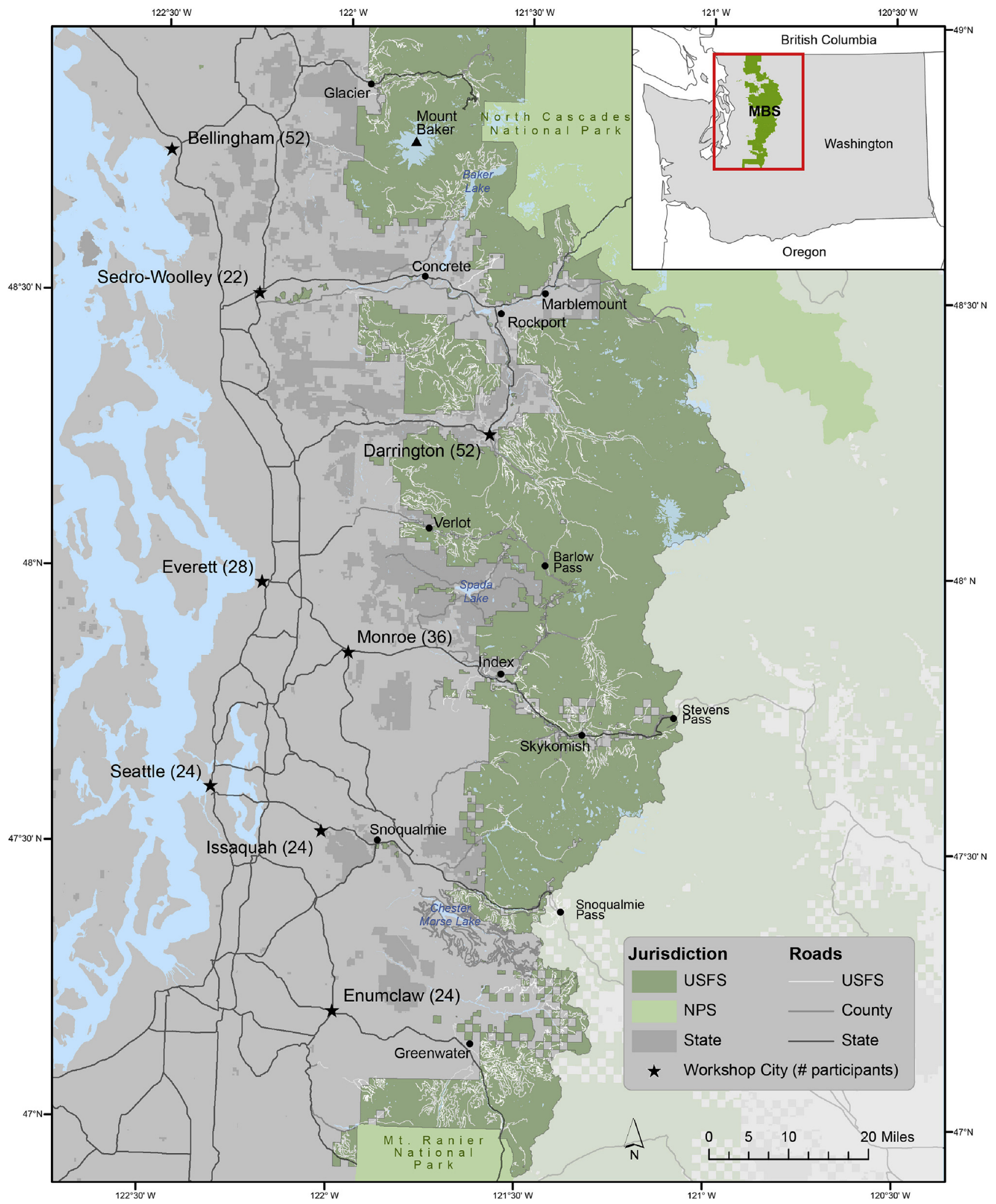

Fig. 1. Mt Baker-Snoqualmie National Forest and public engagement workshop locations.

location. In areas with many destination dots in one location, the points were relocated to the end of the route travelled. Destinations points that were placed away from the road system, such as in wilderness areas, were also moved to the end of the route travelled.

The density of workshop destinations (per square mile) was calculated using a kernel function to create a smooth raster surface from the individual points. To account for differences in how often participants went to the places marked, the destinations were weighted based on the frequency of use noted on the worksheets. Destinations listed as being used "several times a week" or "several 
times a month" were weighted twice as much as those listed as being used "several times a year" or "about once or twice a year or less".

Without an interactive mapping component in the online survey, road names and destinations written by participants were the only source of spatial data. The analyses were limited to destinations because the road data had numerous errors and inconsistencies. To create comparable data from the workshop (mapped points) and online destinations (written names), a method was developed to identify general destination areas. Optimized hotspot analysis was employed using the workshop destination points to create statistically significant aggregate points. These aggregate points were then used to create Thiessen polygons (where all space within the polygon is closer to its associated point than any other input point), which partitioned the entire area covered by the MBSNF. The Thiessen polygons were manually inspected to determine whether consistent and accurate groupings were formed.

\subsection{Determination of urban/rural areas}

To explore whether there were differences in how urban and rural residents mapped, the zip codes of the participants were divided into six groupings (Fig. 2). The groupings were designed to have a relatively even distribution of participants among the six groups while creating boundaries coherent with urban and rural geographies. King County, which represents a dense metropolitan area, was divided into northern and southern areas. Since each of the zip code groupings includes areas that span the urban-rural continuum, the North King County zip code grouping was selected to represent the most urbanized end of the continuum. The Mountain Loop area, which includes communities along the Mountain Loop Highway, including communities of Granite Falls, Darrington, and Arlington, was considered to represent the most rural end of the continuum.

\section{Results}

Fig. 3 provides a road map to how the data were broken down for analysis. Data from the community workshops and from the online survey were analyzed separately. The datasets were disaggregated by socio-demographics, activity, and zip code group. Each zip code group was then disaggregated by sociodemographics and activity.

\subsection{Socio-demographics}

The socio-demographics for the workshops and online survey participants are summarized in Table 1 . Workshop participants were mostly male ( 74 percent), with an average age of 55 , and had lived in western Washington for an average of 37 years. Forty-one percent participated as representatives of organizations or agencies. Half the participants were between the ages of 50 and 69, and another 16 percent were older than 70 . Most had at least a fouryear college degree and relatively high incomes.

Online survey participants were predominantly male (71 percent), with an average age of 51 years, and had spent an average of 32 years living in their community. Online survey participants tended to be somewhat younger than the workshop participants, with a smaller percentage in the 70 and older category. They also tended to have a higher level of education and higher incomes than workshop participants. Only four percent of the online participants represented organizations or agencies, a striking contrast with the 41 percent in the workshops. Unlike the workshop participants, all of whom were residents of Washington, the online participants included residents of 20 states.

Table 1 also shows how the online and workshop participants differed from the general population in the study area. Overall, both the online and workshop participants were more likely than the general population to be male. They were also older and had more education and higher incomes than the general population.

When participants were divided into zip code groups (Table 2), it became apparent that the workshops attracted a higher percentage of rural participants while the online survey had far more urbanites. Although fewer rural residents participated in the public engagement processes, the per capita participation rate was much higher for rural areas than for the urban areas.

\subsection{Comparison of online and workshop destinations}

Although the online survey participants mapped on average many fewer destinations than workshop participants, the total number of destinations mapped during the online survey was more than twice that mapped during the workshops. Workshop participants' destinations were more likely to be trailhead locations. Online survey participants' destinations were more often lakes, mountains, etc. that were not located directly adjacent to roads. This difference likely reflects the mapping process used in the workshop, i.e., the tracing of a route, leads logically to marking a location where the (driven) path ends.

Aggregating destination locations using the Thiessen polygon method permitted comparison of the two datasets. The general pattern for the spatial distribution of the top 30 destinations, as shown in Fig. 4, was similar for workshop and online participants. For both groups, the most favored locations were skewed toward the northern half of the forest near Mt. Baker. Elsewhere in the forest many of the top destinations were popular with both groups. Workshop participants mapped a secondary, less tightly clustered concentration of top destinations in the middle of the MBSNF. With the exception of the Mt. Baker cluster, the top destinations for the online survey participants were more dispersed across the forest; a pattern that likely reflected a higher percentage of residents of centrally located Seattle.

\subsection{Activities}

Both workshop and online survey participants listed many activities that they engaged in while at their mapped destinations. The activities were classified into eight groups: hiking, winter recreation, motorized recreation, strenuous recreation, observation, collecting/harvesting, relaxation/camping and sociocultural (Table 3). Where possible, categories were created with relatively equal numbers of participants. Hiking, which was by far the most frequently mentioned activity for workshop and online participants was assigned its own category.

Fig. 5 shows the destination densities for four different activities for workshop participants. The use patterns for motorized recreation (Fig. 5A) and strenuous recreation (Fig. 5B) were decidedly different from each other, but these activities were also limited to a relatively small number of hotspots. Strenuous recreation, much of which consisted of climbing, was concentrated primarily around Mt. Baker. Motorized recreation was concentrated in two areas. A southern motorized recreation hotspot was located in an area set aside specifically for ATV use; a northern hotspot was located north of Mt. Baker. Although activities such as collecting/gathering (Fig. 5C) and camping/relaxation (Fig. 5D) had some areas in which they were more concentrated, overall they were more widely distributed through the forest. 


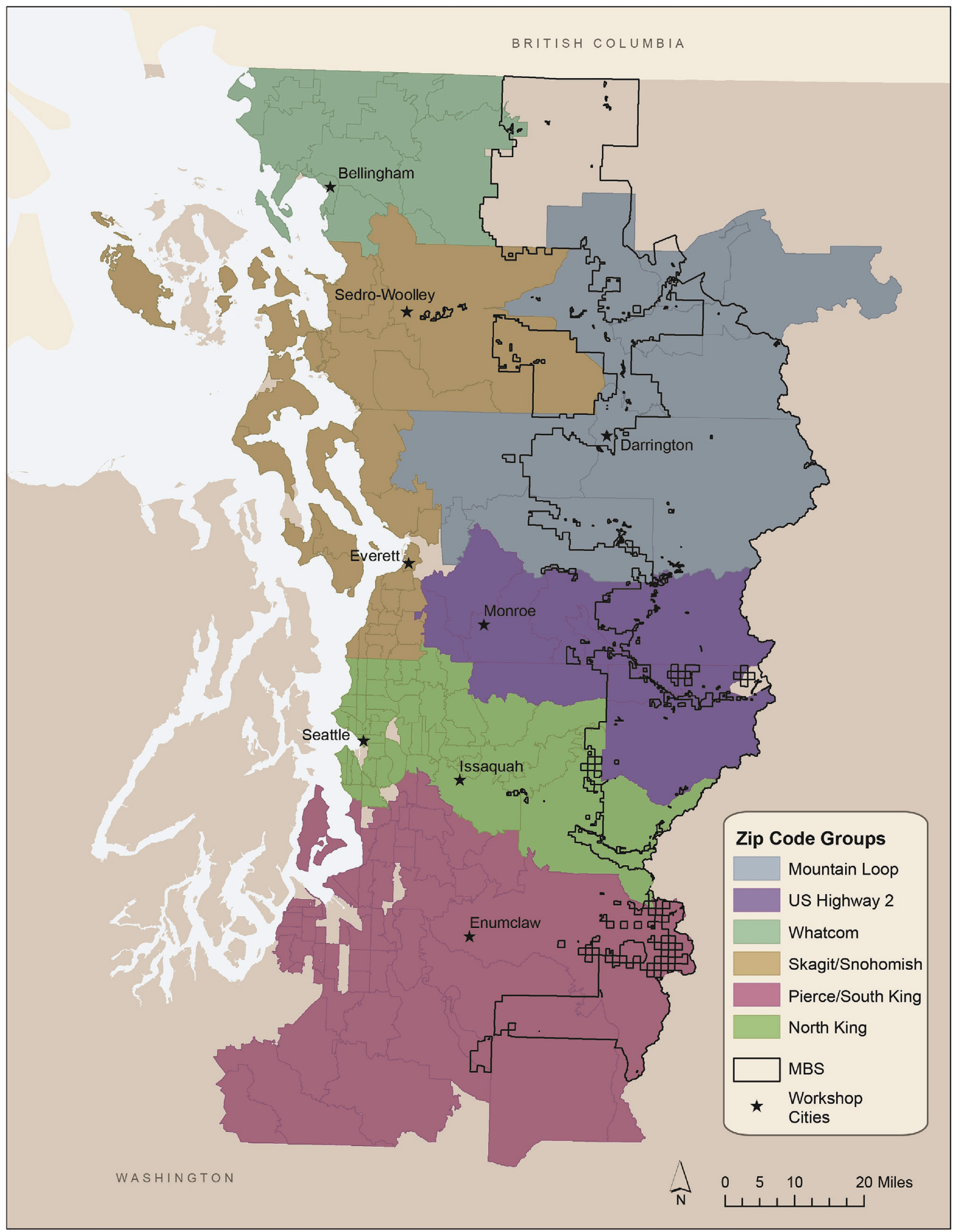

Fig. 2. Survey participant zip code groups. 


\section{MBS Public Engagement}

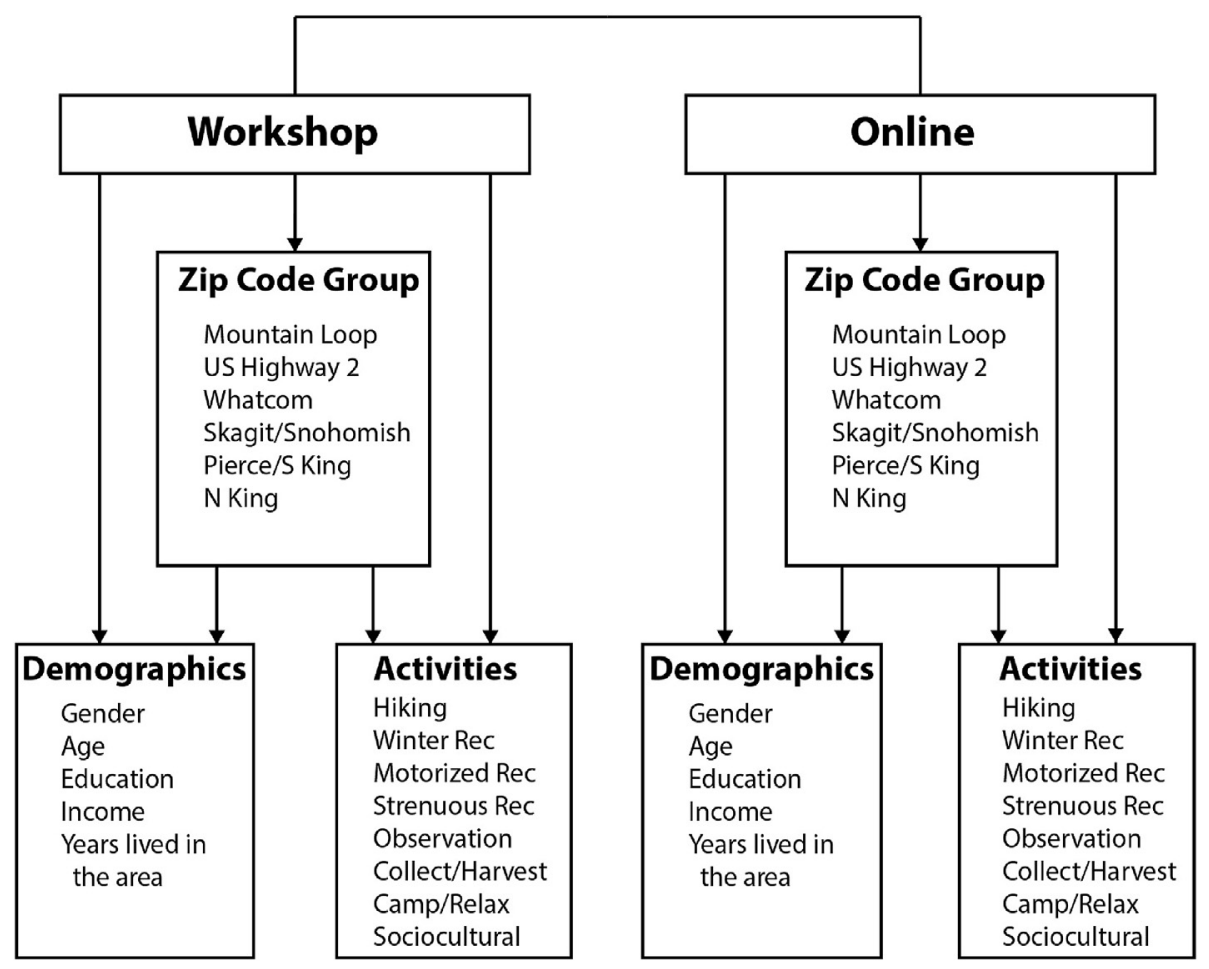

Fig. 3. Outline of the disaggregation of public engagement data for analysis by sub-group.

Table 1

Demographics of workshop and online survey participants.

\begin{tabular}{|c|c|c|c|c|}
\hline & Workshop N = 262 & Online $\mathrm{N}=1548$ & Online (mapped) $\mathrm{N}=727$ & American Community Survey 2015 \\
\hline \multicolumn{5}{|l|}{ Gender } \\
\hline Female & $67(26 \%)$ & $298(29 \%)$ & $194(30 \%)$ & $51 \%$ \\
\hline Male & $189(74 \%)$ & $732(71 \%)$ & $449(70 \%)$ & $49 \%$ \\
\hline Total Respondents & 256 (98\%) & $1030(67 \%$ & $643(88 \%)$ & $2,303,965$ \\
\hline \multicolumn{5}{|l|}{ Age (years) } \\
\hline$<30$ & $13(5 \%)$ & $55(6 \%)$ & $42(7 \%)$ & $22 \%$ \\
\hline $30-49$ & $71(28 \%)$ & $368(37 \%)$ & $220(36 \%)$ & $38 \%$ \\
\hline $50-69$ & $130(51 \%)$ & 465 (47\%) & $287(46 \%)$ & $31 \%$ \\
\hline$\geq 70$ & $41(16 \%)$ & $101(10 \%)$ & $69(11 \%)$ & $9 \%$ \\
\hline Total Respondents & $255(97 \%)$ & $989(64 \%)$ & $618(85 \%)$ & $2,119,622$ \\
\hline \multicolumn{5}{|l|}{ Education } \\
\hline No 4-year degree & $101(40 \%)$ & 309 (30\%) & $159(25 \%)$ & $61 \%$ \\
\hline 4-year degree & $86(34 \%)$ & $386(38 \%)$ & $241(38 \%)$ & $25 \%$ \\
\hline Masters or higher & $65(26 \%)$ & $321(32 \%)$ & $232(37 \%)$ & $14 \%$ \\
\hline Total Respondents & 252 (96\%) & $1016(66 \%)$ & $632(87 \%)$ & $1,964,179$ \\
\hline \multicolumn{5}{|l|}{ Income (\$) } \\
\hline$\leq 50 \mathrm{k}$ & $63(28 \%)$ & $185(20 \%)$ & $111(20 \%)$ & $37 \%$ \\
\hline $50 \mathrm{k}-100 \mathrm{k}$ & 99 (44\%) & 353 (39\%) & $222(39 \%)$ & $32 \%$ \\
\hline$>100 \mathrm{k}$ & $61(27 \%)$ & $373(41 \%)$ & $234(41 \%)$ & $31 \%$ \\
\hline Total Respondents & $223(85 \%)$ & 911 (59\%) & 567 (78\%) & $1,120,091$ \\
\hline Average length of time in area (years) & 37 & 31 & 31 & \\
\hline
\end{tabular}

\subsection{Urban-rural comparison}

Table 4 summarizes the differences in demographic characteristics between workshop participants and online survey participants for the most urban zip code group (North King County) and the most rural zip code group (Mountain Loop). Online participants in North King County tended to be more highly educated than their workshop counterparts ( 51 percent of the online participants had a Master's degree or higher versus 41 percent for workshop participants), but otherwise the two groups were similar. For the
Mountain Loop zip code group, online participants tended to be younger and had higher incomes than their workshop counterparts. However, compared with their counterparts in the Mountain Loop area, the North King County workshop and online survey participants tended to be younger, had not lived in the area as long, had more formal education, and fewer were in the lower income category.

As indicated in Fig. 6, the top 30 destinations for the most urban and rural areas differed greatly in where they were located and in their spatial configuration. The Mountain Loop workshop 
Table 2

Population of zip code groups.

\begin{tabular}{|c|c|c|c|c|c|c|}
\hline Zip Code Group & Workshop Participants & Online Participants (mapped) & Total Participants & Population (2010 census) & Population/1000 & Participants/1000 \\
\hline Mountain Loop ${ }^{\mathrm{a}}$ & $50(19 \%)$ & $35(6 \%)$ & $85(10 \%)$ & 84,625 & 85 & 1 \\
\hline US Highway $2^{\mathrm{b}}$ & $33(13 \%)$ & $36(6 \%)$ & $69(8 \%)$ & 107,330 & 107 & 0.64 \\
\hline Whatcom ${ }^{\mathrm{c}}$ & $51(20 \%)$ & $102(16 \%)$ & $153(17 \%)$ & 196,834 & 197 & 0.78 \\
\hline Skagit/Snohomish $^{\mathrm{d}}$ & $55(21 \%)$ & $146(23 \%)$ & $201(23 \%)$ & 709,687 & 710 & 0.28 \\
\hline Pierce/South King County ${ }^{\mathrm{e}}$ & $28(11 \%)$ & $79(12 \%)$ & $107(12 \%)$ & $1,033,078$ & 1033 & 0.10 \\
\hline \multirow[t]{2}{*}{ North King County ${ }^{\mathrm{f}}$} & $44(17 \%)$ & $233(37 \%)$ & $277(31 \%)$ & $1,189,755$ & 1190 & 0.23 \\
\hline & 259.99 & 630 & 892 & & & \\
\hline
\end{tabular}

a Rural communities including Darrington.

b Suburban Snohomish county and rural communities including Monroe.

c The city of Bellingham and surrounding rural areas.

d Puget Sound cities north of Seattle, such as Everett, and some rural communities, such as Sedro Woolley.

e Predominantly urban/suburban areas with pockets of rural communities such as Enumclaw.

${ }^{\mathrm{f}}$ Densely populated urban areas (Seattle) plus suburban communities (Issaquah) and some outlying rural communities.
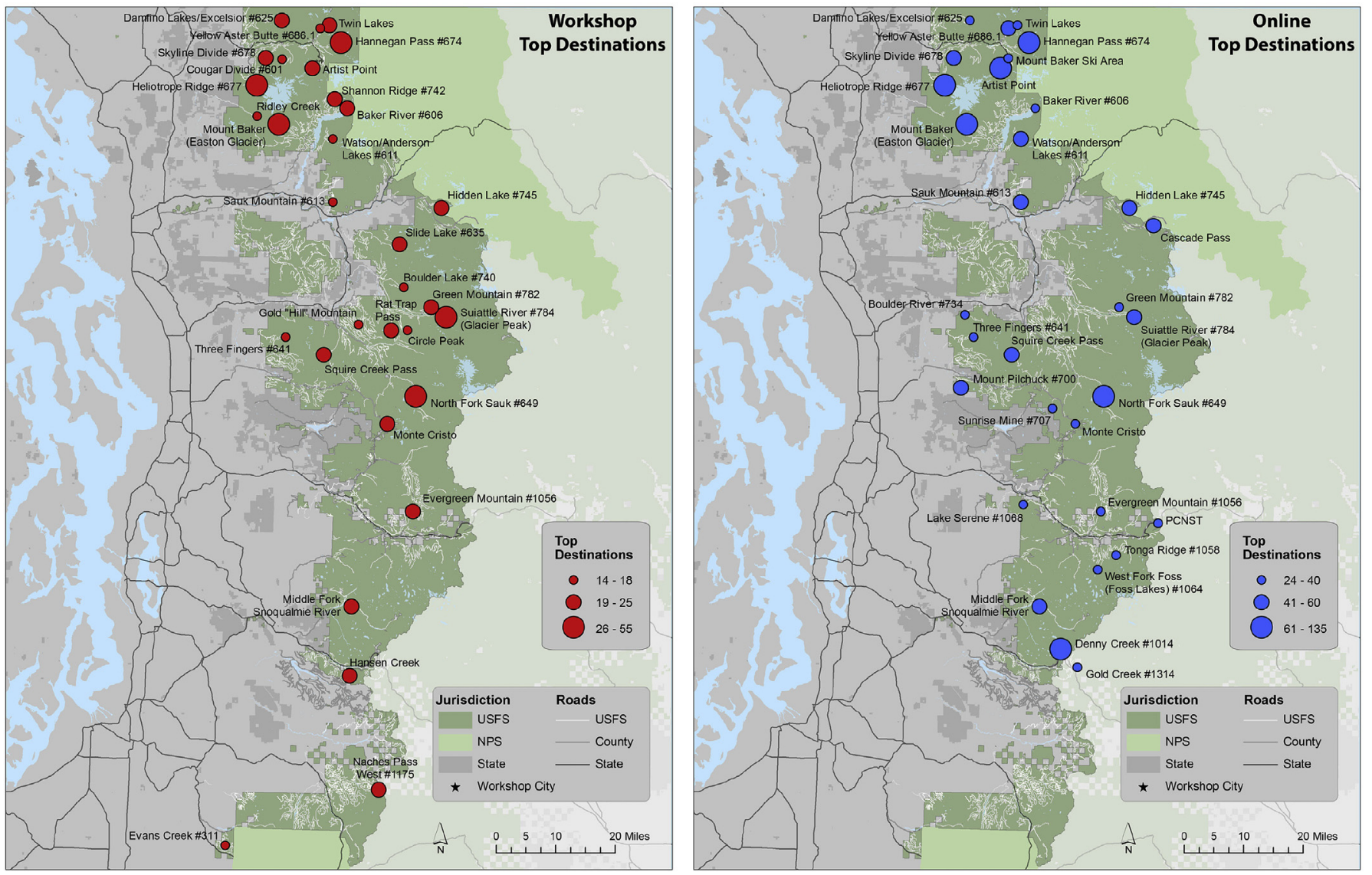

Fig. 4. Top destinations of workshop and online survey participants.

participants' destinations were nearly all located within a short distance of Darrington (Fig. 6A), forming a very tight cluster of points. Although there is some clustering of the North King County workshop participants' destinations around Snoqualmie Pass (Fig. 6C), which is located an hour's drive from Seattle, overall the North King County workshop destinations are comparatively dispersed over much of the MBSNF. A similar pattern is present in the online participant results, with Mountain Loop residents' destinations being relatively tightly clustered near Darrington (Fig. 6B), and North King County residents' destinations widely scattered (Fig. 6D). For both zipcode groups, the online participants' destinations were more dispersed than the workshop participants' destinations. The transportation network linking population centers to the national forest likely explains some of the difference between rural and urban participants' mapping patterns. North King County residents have ready access to a federal highway that parallels the Cascade Range and intersects with the major eastwest highways that pass through the MBSNF. Consequently, much of the national forest is located within a 2-hour or less drive for most North King County residents. Although Mountain Loop residents can easily access forest roads near their homes, because they are not located along any of the major highways they must travel much further to reach other parts of the forest.

Table 5 summarizes the activities reported by online and 
Table 3

Activities of workshop and online survey participants.

\begin{tabular}{|c|c|c|c|c|c|}
\hline \multirow[t]{2}{*}{ Activity Class } & \multirow[t]{2}{*}{ Examples } & \multicolumn{2}{|c|}{ Workshop } & \multicolumn{2}{|c|}{$\begin{array}{l}\text { Online (mapped } \\
\text { data) }\end{array}$} \\
\hline & & Count $^{\mathrm{a}}$ & Percentage $^{b}$ & Count $^{\mathrm{a}}$ & Percentage $^{b}$ \\
\hline Hiking & hiking & 913 & $53 \%$ & 1613 & $69 \%$ \\
\hline $\begin{array}{l}\text { Winter } \\
\text { recreation }\end{array}$ & $\begin{array}{l}\text { cross-country skiing, snowshoeing, snowboarding, ice glacier skills, snow activities, glacier travel, snow arrest } \\
\text { practice, splitboard }\end{array}$ & 207 & $12 \%$ & 361 & $15 \%$ \\
\hline $\begin{array}{l}\text { Motorized } \\
\text { recreation }\end{array}$ & $\begin{array}{l}\text { snowmobiling, drive, motorcycle, } 4 \times 4 \text {, off-road, trail ride, jeep, motorized rec, dual sport, ride, trail racing, travel, } \\
\text { touring }\end{array}$ & 341 & $20 \%$ & 140 & $6 \%$ \\
\hline $\begin{array}{l}\text { Strenuous } \\
\text { recreation }\end{array}$ & $\begin{array}{l}\text { backpacking, mountaineering, guided ascents, climbing, alpine skills, exercise, rock climbing, summit peaks, run, } \\
\text { packing, swimming, rafting, mountain bike, biking, guide service }\end{array}$ & 370 & $21 \%$ & 801 & $34 \%$ \\
\hline Observation & $\begin{array}{l}\text { photography, views, exploring, watching, wildlife, scenery, star gaze, view, enjoy view and nature, sightseeing, } \\
\text { observing, birding, look }\end{array}$ & 321 & $19 \%$ & 433 & $18 \%$ \\
\hline $\begin{array}{l}\text { Collecting/ } \\
\text { Harvesting }\end{array}$ & $\begin{array}{l}\text { hunting, fishing, harvesting, berry picking, gathering, Christmas tree, rockhounding, wood, pick plants, metal } \\
\text { detecting, gold panning, rock collecting, foraging, collecting }\end{array}$ & 183 & $11 \%$ & 274 & $12 \%$ \\
\hline $\begin{array}{l}\text { Camping/ } \\
\text { Relaxation }\end{array}$ & camping, visit, overnights, hot spring, celebrate, picnic, leisure, relax, laughing, having fun, solitude, get away & 329 & $19 \%$ & 452 & $19 \%$ \\
\hline Sociocultural & $\begin{array}{l}\text { instruction (work), management, trail work, study/learn/teach/education, guiding, search and rescue, research, } \\
\text { logging, fire-fighting, employment, weed detection, restore, monitoring, family/friends/visitors, festival, cultural, } \\
\text { history, tourism, riding horses/mules }\end{array}$ & 226 & $13 \%$ & 247 & $11 \%$ \\
\hline
\end{tabular}

workshop participants from the Mountain Loop and North King County zip code groups. Clear differences existed between these urban and rural participants in some activities. For example, Mountain Loop participants were much more likely than their North King County counterparts to map berry picking or hunting sites. Conversely, North King County participants were more likely than their Mountain Loop counterparts to map strenuous recreation sites. Urban and rural participants mapped sites for camping/ relaxation and hiking with nearly equal frequency. These patterns held true for both workshop and online participants in the two zip code groups. However, important differences existed within the zip code groups between the types of activities mapped by online and workshop participants. For both the North King County and Mountain Loop participants, climbers and winter recreationalists had a strong online presence. Among the Mountain Loop online participants, nearly twice as many motorized recreation destinations were mapped as for workshop participants. The results were the reverse for the North King County zip code group, where workshop participants mapped motorized recreation sites more frequently than their online counterparts.

\section{Discussion}

This study examined whether two commonly used PPGIS approaches to public engagement - community mapping workshops and interactive online mapping surveys - reached different publics as well as variations in public visitation by location and activity. It also explored differences between the most urban and most rural participants in the destinations they mapped and the activities that they engaged in at those places. Both analyses highlight the importance for managers who use PPGIS as a public engagement tool to understand how the data collection approach utilized is likely to affect which segments of the public can or will participate (Haddock and Quinn, 2016; Reed, 2008). Additionally, the urbanrural analysis illustrates the importance of disaggregating PPGIS data when reporting results to land managers and policy makers, drawing attention to the need for understanding the spatial use and activity type differences of participants living at different places along an urban-rural continuum.

This research on the MBSNF's sustainable roads public engagement process has important implications for the use of PPGIS as a public engagement tool. With respect to the study's first objective, the MBSNF case supports Brown et al.'s (2014) findings that community mapping workshops are likely to attract a different set of participants than online mapping surveys. In both studies, workshop participants were more likely than online participants to be men, somewhat older, and rural or small town residents. However, in the case of the MBSNF, the differences between the two groups were a matter of degree. In many respects, the two groups were more similar to each other than either was to the general population. In this sense, one could argue that, despite their differences, the two PPGIS methods attracted similar segments of the public. Other approaches, such as targeted focus groups with specific subpopulations, may be needed to reach a broader range of forest users (Biedenweg et al., 2014).

In both the MBSNF and Brown et al.'s (2014) studies, substantial overlap existed between online and workshop participants in the sites marked as important for recreation. However, the MBSNF study revealed that workshop and online participants differed in the types of recreational activities that they engage in at those places. The implication for planners is that identifying the types of activities likely to be impacted by proposed management actions will require the use of a combination of workshop and online survey PPGIS data gathering strategies so as to reach these distinct population segments (Haddock and Quinn, 2016; Measham et al., 2011).

Another finding from the MBSNF process is that a much higher percentage of workshop participants were representatives of organizations or agencies, a result that concurs with Brown et al.'s (2014) PPGIS study in Alaska. Brown et al. attributed this difference to their use of stakeholder groups to recruit workshop participants. However, in the MBSNF case, stakeholder groups recruited both workshop and online survey participants, indicating that other factors besides stakeholder involvement in recruitment are at work. It may be that stakeholder group representatives are more willing to invest time in public mapping workshops, they may be more likely to be paid to attend the workshops, have greater familiarity with workshops, or see workshops as more effective avenues for influencing public decisions (Haddock and Quinn, 2016). An important implication for public engagement strategies is that workshops may be more suited to engaging organized stakeholders, and online surveys may be more effective for engaging a broader public (Brown et al., 2014).

The MBSNF study also supports the proposition that online 

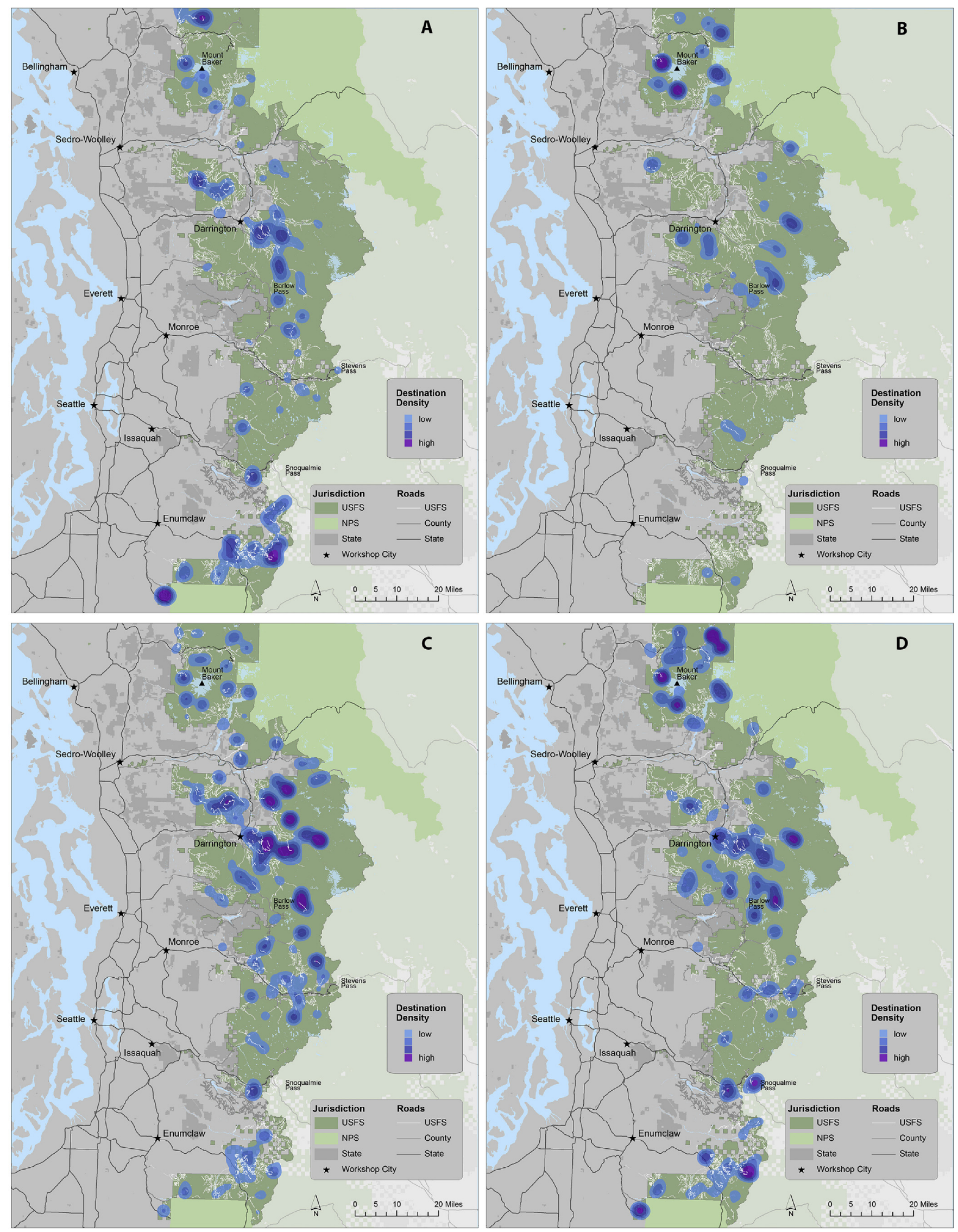

Fig. 5. Densities of four workshop activities: A) motorized recreation, B) strenuous recreation, C) collecting, and D) camping/relaxation. 
Table 4

Demographics of workshop and online survey participants for the most urban and most rural zip code areas.

\begin{tabular}{|c|c|c|c|c|}
\hline & \multicolumn{2}{|l|}{ Workshop } & \multicolumn{2}{|l|}{ Online (mapped) } \\
\hline & Urban (North King County) $N=44$ & Rural (Mtn. Loop) $\mathrm{N}=50$ & Urban (North King County) $N=231$ & Rural (Mtn. Loop) $\mathrm{N}=33$ \\
\hline \multicolumn{5}{|l|}{ Gender } \\
\hline Female & $11(26 \%)$ & $14(28 \%)$ & $55(27 \%)$ & $7(25 \%)$ \\
\hline Male & $31(74 \%)$ & $36(72 \%)$ & $148(73 \%)$ & $21(75 \%)$ \\
\hline Total Respondents & $42(95 \%)$ & $50(100 \%)$ & $203(88 \%)$ & $28(85 \%)$ \\
\hline \multicolumn{5}{|l|}{ Age (years) } \\
\hline$<30$ & $2(5 \%)$ & $2(4 \%)$ & $10(5 \%)$ & $2(7 \%)$ \\
\hline $30-49$ & $18(44 \%)$ & $12(24 \%)$ & $90(45 \%)$ & $9(33 \%)$ \\
\hline $50-69$ & $19(46 \%)$ & $26(52 \%)$ & $87(44 \%)$ & $15(56 \%)$ \\
\hline$>=70$ & $2(5 \%)$ & $10(20 \%)$ & $11(6 \%)$ & $1(4 \%)$ \\
\hline Total Respondents & $41(93 \%)$ & $50(100 \%)$ & $198(86 \%)$ & $27(82 \%)$ \\
\hline \multicolumn{5}{|l|}{ Education } \\
\hline No 4-year degree & $6(15 \%)$ & $24(50 \%)$ & $24(12 \%)$ & $15(53 \%)$ \\
\hline 4-year degree & $18(44 \%)$ & $12(25 \%)$ & $75(37 \%)$ & $8(29 \%)$ \\
\hline Masters or higher & $17(41 \%)$ & $12(25 \%)$ & $102(51 \%)$ & $5(18 \%)$ \\
\hline Total Respondents & $41(93 \%)$ & $48(96 \%)$ & $201(87 \%)$ & $28(85 \%)$ \\
\hline \multicolumn{5}{|l|}{ Income $(\$)$} \\
\hline$<=50 \mathrm{k}$ & $3(9 \%)$ & $14(33 \%)$ & $32(18 \%)$ & $5(20 \%)$ \\
\hline $50 \mathrm{k}-100 \mathrm{k}$ & $13(39 \%)$ & $20(47 \%)$ & $58(32 \%)$ & $12(48 \%)$ \\
\hline$>100 \mathrm{k}$ & $17(52 \%)$ & $9(21 \%)$ & $91(50 \%)$ & $8(32 \%)$ \\
\hline Total Respondents & $33(75 \%)$ & $43(86 \%)$ & $181(78 \%)$ & $25(76 \%)$ \\
\hline Average length of time in area (years) & 28 & 42 & 29 & 39 \\
\hline
\end{tabular}

mapping surveys can be an effective tool for engaging individuals from outside the study region (Rinner and Bird, 2009). This finding is particularly relevant for public engagement processes involving federal lands where management decisions affect a national public (Brown, 2012). However, in some contexts, such as isolated rural areas where distances are great but distrust of government planners is high, online public engagement methods may not be effective (Measham et al., 2011). Other local considerations may also shape participation patterns. In the MBSNF case, for example, extreme traffic congestion in the region's urban areas may be as formidable a barrier to participation in workshops as long distances in rural locations.

Although online public engagement strategies are becoming increasingly common (Brown and Kyätta, 2014), in implementing the MBSNF's online survey a number of problems emerged which call into question the advisability of relying solely on online PPGIS approaches. The average number of destinations mapped per online survey participant was less than half that for workshop participants, a phenomenon that has been observed elsewhere (Brown, 2016). Moreover, fewer than half of the online participants provided useful spatial data whereas nearly all of the workshop participants provided mappable data. Use of an interactive mapping application (rather than pdf reference maps) for the online survey would likely have resulted in more reliable spatial data for the destination points (Brown, 2016). However, it is questionable that an interactive map would have done any better at collecting data about the routes participants used to get to favored destinations given that current interactive mapping technologies are not well-suited to mapping linear data (Poplin, 2015). Additionally, scale is an issue with an interactive map in contexts where the geographic extent encompassed by the map is very large. Even if the map has a zoom function, navigating one's way around a large area can be tedious and time-consuming, increasing the likelihood that participants will abandon the survey prior to completion. Given the level of technical skill required in many PPGIS applications, White et al. (2010) and Babelon et al. (2017) recommend that online PPGIS approaches be considered just one of a set of public engagement tools.

In the MBSNF case, the maps used in the workshops were big enough that participants could see a large area at once, making it much easier for them to locate roads and sites. Additionally, the workshops provided a venue in which participants could engage in conversation with each other and Forest Service officials about prospective travel management actions. If the goal of a public engagement process is to encourage dialogue, social learning, or build trust, workshops may be more appropriate than online PPGIS approaches (Measham et al., 2011). However, participating in workshops requires a substantially greater time investment on the part of participants than filling out an online mapping survey. Additionally, space limitations may limit the number of people who can be accommodated at workshops, and some individuals may have scheduling conflicts that preclude their participation (Measham et al., 2011).

With respect to the study's second objective, the MBSNF case lends support to the hypothesis that urban and rural residents are likely to differ in terms of their spatial uses and activity patterns associated with forest road networks. The only other PPGIS study (Brown et al., 2015a) that has explicitly examined differences in urban and rural residents' mapping patterns also found that rural residents' favored locations were less dispersed than those of urban and suburban residents. Brown et al. attribute some of the difference to occupational differences with rural-based farmers having a more reduced range than urban-based natural resource and conservation professionals. It is unknown what role occupation may have played in the MBSNF study since occupational differences were not included in the analysis. Brown et al. also identified distance from the coast as a factor, with residents closer to the coast mapping features over a smaller area. The opposite pattern was observed in the MBSNF case, with the coastally proximate North King County participants having a more spatially dispersed mapping pattern than the inland Mountain Loop participants. As described in the results section, the transportation network structure in the MBSNF study area may explain much of the difference in mapping patterns between the two sub-groups. One management implication of greater clustering of rural residents' mapped features in the MBSNF case is that they are more likely to be displaced from their favorite destinations by forest road closures occurring near their residences than are urban residents. Importantly, within the urban and rural subgroups participating in the MBSNF process, the spatial use patterns of online and workshop participants' 

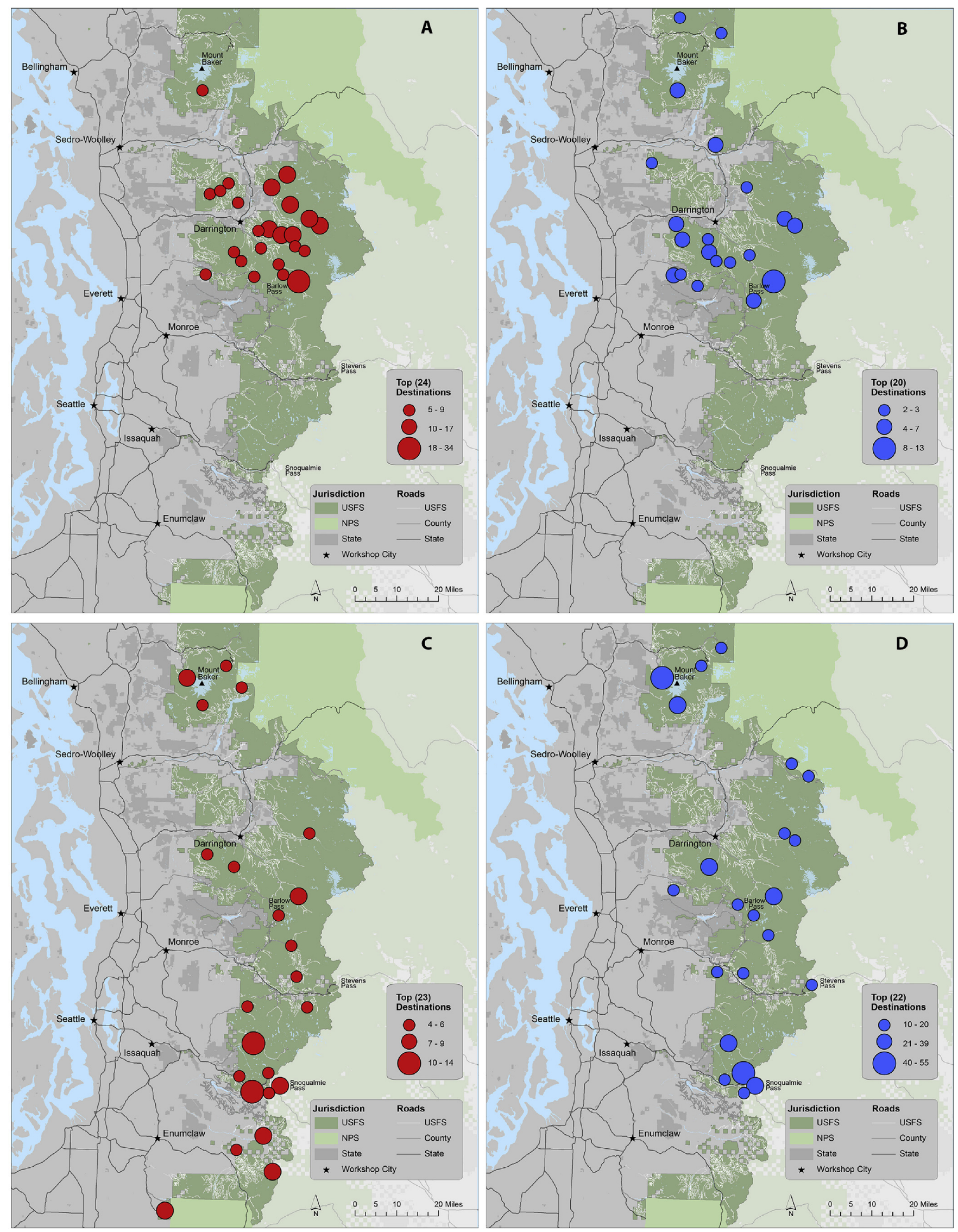

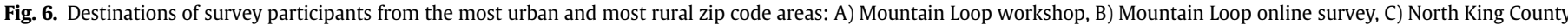
workshop, and D) North King County online survey. 
Table 5

Comparison of activities of workshop and online survey participants for the most urban and most rural zip code areas.

\begin{tabular}{|c|c|c|c|c|c|c|}
\hline \multirow[t]{2}{*}{ Activity } & \multicolumn{3}{|l|}{ Workshop $^{\mathrm{a}, \mathrm{b}}$} & \multicolumn{3}{|c|}{ Online (mapped) ${ }^{\mathrm{a}, \mathrm{b}}$} \\
\hline & Total $\mathrm{N}=1728$ & Mtn. Loop N = 363 & North King County $N=269$ & Total $\mathrm{N}=2350$ & Mtn. Loop $\mathrm{N}=118$ & North King County $N=752$ \\
\hline Hiking & $913(53 \%)$ & $189(52 \%)$ & $123(46 \%)$ & $1613(69 \%)$ & $78(66 \%)$ & $476(63 \%)$ \\
\hline Winter recreation & $207(12 \%)$ & $19(5 \%)$ & $31(12 \%)$ & $361(15 \%)$ & $19(16 \%)$ & $145(19 \%)$ \\
\hline Motorized recreation & $341(20 \%)$ & $33(9 \%)$ & $78(29 \%)$ & $140(6 \%)$ & $21(18 \%)$ & $16(2 \%)$ \\
\hline Strenuous recreation & $370(21 \%)$ & $45(12 \%)$ & $70(26 \%)$ & $801(34 \%)$ & $31(26 \%)$ & $350(47 \%)$ \\
\hline Observation & $321(19 \%)$ & $93(26 \%)$ & $23(9 \%)$ & $433(18 \%)$ & $35(30 \%)$ & $130(17 \%)$ \\
\hline Collecting/Harvesting & $183(11 \%)$ & $153(42 \%)$ & $23(9 \%)$ & $274(12 \%)$ & $29(25 \%)$ & $48(6 \%)$ \\
\hline Camping/Relaxation & $329(19 \%)$ & $77(21 \%)$ & $52(19 \%)$ & $452(19 \%)$ & $25(21 \%)$ & $126(17 \%)$ \\
\hline Sociocultural & $226(13 \%)$ & $48(13 \%)$ & $25(9 \%)$ & $247(11 \%)$ & $28(24 \%)$ & $68(9 \%)$ \\
\hline
\end{tabular}

$\mathrm{N}$ is the number of destinations noted.

b Since participants could list more than one activity, percentage values do not add to $100 \%$.

destinations were broadly similar but the types of activities they engaged in were very different. This finding suggests that, depending on the context, it may be important to use multiple engagement methods even within population sub-groups.

Questions also emerged from the study regarding the degree to which one can assume that PPGIS data are reliable. Both the workshop and online survey approaches used by the MBSNF assumed that participants had a sufficiently detailed knowledge of the road system in the forest to be able to identify favored sites and could accurately read maps. However, during the workshops many participants struggled with mapping routes and finding specific places, often relying on fellow participants for help. They experienced these problems despite having a large and detailed map at their fingertips, a problem that has been reported elsewhere (Nahuelhual et al., 2016). Comparable observations for the online survey participants were not available, but it is reasonable to assume that users of the online maps would have had similar problems given that studies have found that users experience challenges in navigating web-based maps (Babelon et al., 2017; Poplin, 2015). More usability studies, such as Poplin's (2015) experiment looking at how different types of users interacted with an online PPGIS mapping application in Germany, are needed to improve understandings of how different types of users interact with these technologies. Equally important, research on how different ways of engaging with maps might affect the quality of spatial data is lacking. As the field of PPGIS matures, improving understandings of how people engage with different types of maps and what the ramifications of different mapping technologies are for spatial data quality are areas that are ripe for research.

\section{Conclusion}

Our study shows that different constituencies were reached through the online and workshop approaches. If the online survey had been the only approach used, the use and activity patterns of rural residents would have been obscured. On the other hand, if only the workshops had been used, the use and activity patterns of the urban community would have been less apparent. Our study has important management implications at a time when government agencies are increasingly relying online public engagement strategies. It suggests that the growing tendency for agencies to rely on online public engagement applications may result in leaving out important constituencies. Specifically, our analysis suggests that environmental managers who wish to engage both urban and rural constituencies will need to use more than one type of public engagement strategy. It also highlights the importance for managers to have an understanding of which public engagement strategies are appropriate for different constituencies.

Disaggregating the data during analysis allows one to see differences in the places that matter to different types of people, and to tease out which groups' preferences are dominating spatial patterns. While overall patterns of use are important, it is equally critical to understand how different segments of the population use the forest, where they go, and which routes they take to get there. Likewise, when considering management actions, a residency analysis can shed light on how particular actions might affect different communities. On the MBSNF, there were at least two distinct constituencies (i.e., urban and rural) whose concerns would need to be acknowledged when making decisions about which roads to close on the MBSNF. In other management contexts, breakdowns by age, gender, income level, and length of residency may yield similarly striking differences in spatial patterns of use. Fine-level analyses of these types are useful for identifying more clearly the population segments and activity groups most likely to be affected by proposed management actions. The MBSNF public engagement project also points to the importance of improving understandings of how different methods and study designs are likely to affect who maps, how they map, and what they map (or do not map). Doing so will require advances in our understandings of how map size, amount of detail on the map, presence of others during the mapping process, and other variables affect both how people interact with maps and the quality of mapped data.

\section{Acknowledgements}

We thank Portland State University students, Patrick Foster, Lindsay Spell, and Jenai Fitzpatrick for their help with GIS data processing, and Mike Psaris for his assistance with the GIS analyses. We acknowledge as well the important roles played by the Sustainable Roads Cadre and the MBSNF staff in the data collection process, especially Rene Bodine, Amy Live, and Mike Schlafmann. This study was supported by the USDA-Forest Service Pacific Northwest Research Station (Contracts \# 2012-CR-11261985-084 and 2011-CR-1126-1975-087), The Wilderness Society, and the Mount Baker-Snoqualmie National Forest.

\section{References}

Alessa, N., Kliskey, A., Brown, G., 2008. Social-ecological hotspots mapping: a spatial approach for identifying coupled social-ecological space. Landscape Urban Plan. 85 (1), 27-39.

Babelon, I., Ståhle, A., Balfors, B., 2017. Toward cyborg PPGIS: exploring sociotechnical requirements for the use of web-based PPGIS in two municipal planning cases, Stockholm region. Sweden. J Environ. Plan. Manage. 60 (8), 1366-1390.

Bathrellos, G.D., Gaki-Papanastassiou, K., Skilodimou, H.D., Papanastassiou, P., Chousianitis, K.G., 2012. Potential suitability for urban planning and industry development using natural hazard maps and geological-geomorphological parameters. Environ. Earth Sci. 66, 537-548.

Bathrellos, G.D., Gaki-Papanastassiou, K., Skilodimou, H.D., Skianis, G.A., Chousianitis, K.G., 2013. Assessment of rural community and agricultural development using geomorphological-geological factors and GIS in the Trikala prefecture (central Greece). Stoch Environ. Res. Risk A 27, 573-588.

Bathrellos, G.D., Skilodimou, H.D., Chousianitis, K., Youssef, A.M., Pradhan, B., 2017. 
Suitability estimation for urban development using multi-hazard assessment map. Sci. Total Environ. 575, 119-134.

Beverly, J.L., Uto, K., Wilkes, J., Bothwell, P., 2008. Assessing spatial attributes of forest landscape values: an internet-based participatory mapping approach. Can. J. Forest Res. 38 (2), 289-303.

Biedenweg, K., Cerveny, L., McLain, R., 2014. Values mapping with Latino forest users: contributing to the dialogue on multiple land use conflict management. Pract. Anthr. 36 (1), 33-37.

British Columbia, Province of, 2016. 2015 Sub-provincial Population Estimates. BC Stats, Victoria, British Columbia.

Brown, G., 2012. Public participation GIS (PPGIS) for regional and environmental planning: reflections on a decade of empirical research. J. Urban Reg. Inf. Syst. Assoc. 25 (2), 5-16.

Brown, G., 2016. A review of sampling effects and response bias in internet participatory mapping (PPGIS/PGIS/VGI). T GIS 21 (1), 39-56. http://dx.doi.org/ 10.1111/tgis.12207.

Brown, G., Weber, D., 2011. Public participation GIS: a new method for park planning. Landscape Urban Plan. 102, 1-15.

Brown, G., Reed, P., 2012. Values compatibility analysis: using public participation geographic information systems (PPGIS) for decision support in national forest management. Appl. Spat. Anal. Policy 5 (4), 317-332.

Brown, G., Kyttä, M., 2014. Key issues and research priorities for public participation GIS (PPGIS): a synthesis based on empirical research. Appl. Geogr. 46, 122-136.

Brown, G., Raymond, C.M., Corcoran, J., 2015a. Mapping and measuring place attachment. Appl. Geogr. 57, 42-53.

Brown, G., de Brie, K., Weber, D., 2015b. Identifying public land stakeholder perspectives for implementing place-based land management. Landscape Urban Plan. 139, 1-15.

Brown, G., Donovan, S., Pullar, D., Pocewicz, A., Toohey, R., Ballesteros-Lopez, R., 2014. An empirical evaluation of workshop versus survey PPGIS methods. Appl. Geogr. 48, 42-51.

Carver, S., Watson, A., Waters, T., Roian, M., Gunderson, K., Davis, B., 2009. Developing computer-based participatory approaches to mapping landscape values for landscape and resource management. In: Geertman, S., Stillwell, J. (Eds.), Planning Support Systems Best Practices and New Methods. Springer, Dordrecht, The Netherlands, pp. 431-448.

Cordell, H.K., 2012. Outdoor Recreation Trends and Futures: a Technical Document Supporting the Forest Service 2010 RPA Assessment. General Technical Report SRS-150. US Department of Agriculture, Forest Service, Southern Research Station, Asheville, NC.

Daniel, T.C., Muhar, A., Arnberger, A., Aznar, O., Boyd, J.W., Chan, K.M.A., Costanza, R., Elmqvist, T., Flint, C.G., Gobster, P.H., Grêt-Regamey, A., Lave, R., Muhar, S., Penker, M., Ribe, R.G., Schauppenlehner, T., Sikor, T., Soloviy, I., Spierenburg, M., Taczanowska, K., Tam, J., von der Dunk, A., 2012. Contributions of cultural services to the ecosystem services agenda. P. Natl. Acad. Sci. USA 109 (23), 8812-8819. http://dx.doi.org/10.1073/pnas.1114773109.

Dwyer, J.F., 1994. Customer Diversity and the Future Demand for Outdoor Recreation. General Technical Report RM-252. US Department of Agriculture, Forest Service, Rocky Mountain Research Station, Fort Collins, CO.

Ellis, M., Gunton, T., Rutherford, M., 2010. A methodology for evaluating environmental planning systems: a case study of Canada. J. Environ. Manage. 91, $1268-1277$.

Glucker, A.N., Driessen, P.P.J., Kolhoff, A., Runhaarl, H.A.C., 2013. Public participation in environmental impact assessment: why, who and how? Environ. Impact. Asses. 43, 104-111.

Haddock, R.L., Quinn, M.S., 2016. An assessment of public engagement for access management planning in southwestern Alberta, Canada. J. Environ. Plann. Manage. 59 (7), 1205-1224.

Havlick, D., 2002. No Place Distant. Island Press, Washington D.C.

Luyet, V., Schlaepfer, R., Parlange, M.B., Buttler, A., 2012. A framework to implement stakeholder participation in environmental projects. J. Environ. Manage. 111, 213-219.

McLain, R., Cerveny, L., Besser, D., Banis, D., Todd, A., Rohdy, S., Kimball-Brown, C., 2013a. Mapping Human-environment Connections on the Olympic Peninsula: an Atlas of Landscape Values. Occasional Papers in Geography No. 7. Portland State University, Portland, OR.
McLain, R., Poe, M., Biedenweg, K., Cerveny, L., Besser, D., Blahna, D., 2013b. Making sense of human ecology mapping: an overview of approaches to integrating socio-spatial data into environmental planning. Hum. Ecol. 41, 651-665.

Measham, T.G., Richards, C., Robinson, C.J., Larson, S., Brake, L., 2011. Genuine community engagement in remote dryland regions: natural resource management in Lake Eyre basin. Geog. Res. 49 (2), 171-182.

Millennium Ecosystem Assessment, 2005. Ecosystems and Human Well-being. A Framework for Assessment. Island Press, Washington D.C.

Nahuelhual, L., Ochoa Benra, F., Rojas, F., Ignacio Diaz, G., Carmona, A., 2016. Mapping social values of ecosystem services: what is behind the map? Ecol. Soc. 21 (3), 24. http://dx.doi.org/10.5751/ES-08676-210324.

Pert, P.L., Hill, R., Maclean, K., Dale, A., Rist, P., Schmider, J., Talbot, L., Tawake, L. 2015. Mapping cultural ecosystem services with rainforest aboriginal peoples: integrating biocultural diversity, governance and social variation. Ecosys. Serv. 13, $41-56$.

Pocewicz, A., Nielsen-Pincus, M., 2013. Preferences of Wyoming residents for siting of energy and residential development. Appl. Geogr. 43, 45-55.

Pocewicz, A., Nielsen-Pincus, M., Brown, G., Schnitzer, R., 2012. An evaluation of internet versus paper-based methods for public participation geographic information systems (PPGIS). T GIS 16 (1), 39-53.

Poplin, A., 2015. How user-friendly are online interactive maps? Survey based on experiments with heterogeneous users. Cartogr. Geogr. Inf. Sci. 42 (4), 358-376. http://dx.doi.org/10.1080/15230406.2014.991427.

Predmore, S.A., Stern, M.J., Mortimer, M.J., 2011. Constructing the public: the 'substantive sieve' and personal norms in US Forest Service planning. J. Environ. Plann. Manage. 54, 403-419.

Rawluk, A., Ford, R.M., Neolaka, F.L., Williams, K.J., 2017. Public values for integration in natural disaster management and planning: a case study from Victoria, Australia. J. Environ. Manage. 185, 11-20.

Reed, M.S., 2008. Stakeholder participation for environmental management: a literature review. Biol. Conserv. 141, 2417-2431.

Rinner, C., Bird, M., 2009. Evaluating community engagement through argumentation maps-a public participation GIS case study. Environ. Plann. B 36, 588-601.

Schlossberg, M., Shuford, E., 2005. Delineating ‘public' and 'participation' in PPGIS. J. Urban. Reg. Inf. Sys. Assoc. 16 (1), 15-26.

Sherrouse, B.C., Clement, J.M., Semmens, D.J., 2011. A GIS application for assessing, mapping, and quantifying the social values of ecosystem services. Appl. Geogr. 31, 748-760.

Tulloch, D., 2008. Public participation GIS (PPGIS). In: Kemp, K. (Ed.), Encyclopedia of Geographic Information Science. SAGE Publications, Thousand Oaks, CA, pp. 352-355. http://dx.doi.org/10.4135/9781412953962.n165. . (Accessed 18 March 2017).

U.S. Census Bureau, 2015. American Community Survey 1-year Estimates. Census Reporter Profile Page for Seattle-Tacoma-Bellevue. WA metro area. https:// censusreporter.org/profiles/31000US42660-seattle-tacoma-bellevue-wametro-area/. (Accessed 18 March 2017).

United States Department of Agriculture, Forest Service (USDA-FS), 1990. Land and Resource Management Plan: Mt. Baker-Snoqualmie National Forest. U.S Department of Agriculture, Forest Service, Everett, WA.

USDA-FS, 2010. Visitor Use Report: Mt Baker-Snoqualmie NF. National Visitor Use Monitoring Data Collected FY 2010. USDA-Forest Service, National Visitor Use Monitoring Program. On file with lead author.

USDA-FS, 2012. Travel Analysis Process: a Guidebook. Guidance for Region 5 Forests to Complete Travel Analysis. Pacific Southwest Region, Vallejo, CA. http://www. fs.usda.gov/detail/r5/recreation/travelmanagement/?cid=stelprdb5435245. (Accessed 18 March 2017).

USDA-FS, 2015a. Mt. Baker-Snoqualmie National Forest Forest-wide Sustainable Roads Report. Mt Baker-Snoqualmie National Forest, Everett, WA. www.fs.usda. gov/Internet/FSE_DOCUMENTS/fseprd486757.pdf. (Accessed 18 March 2017).

USDA-FS, 2015b. Sustainable Roads Strategy: Public Engagement Report. Mt BakerSnoqualmie National Forest, Everett, WA. http://www.fs.usda.gov/Internet/FSE_ DOCUMENTS/fseprd486467.pdf. (Accessed 18 March 2017).

White, I., Kingston, R., Barker, A., 2010. Participatory geographic information systems and public engagement within flood risk management. J. Flood Risk Manage. 3, 337-346. 